\title{
Structural Characterization and Infrared and Electrical Properties of the New Inorganic-Organic Hybrid Compound $\left[\mathbf{N}\left(\mathbf{C}_{3} \mathbf{H}_{7}\right)_{4}\right]_{2}\left[\mathbf{H g}_{2} \mathbf{C l}_{6}\right]$
}

\author{
A. Oueslati, ${ }^{1}$ I. Chaabane, ${ }^{1}$ K. Adil, ${ }^{2}$ and F. Hlel ${ }^{1}$ \\ ${ }^{1}$ Laboratoire de l'État Solide, Faculté des Sciences de Sfax, Université de Sfax, 3000 Sfax, Tunisia \\ ${ }^{2}$ Laboratoire des Oxydes et Fluorures, Université du Maine, Avenue Olivier Messiaen, 72085 Le Mans Cedex 05, France \\ Correspondence should be addressed to A. Oueslati; oueslatiabderrazek@yahoo.fr
}

Received 9 June 2012; Accepted 11 August 2012

Academic Editor: Adriana Szeghalmi

Copyright @ 2013 A. Oueslati et al. This is an open access article distributed under the Creative Commons Attribution License, which permits unrestricted use, distribution, and reproduction in any medium, provided the original work is properly cited.

New inorganic-organic hybrid $\left[\left(\mathrm{C}_{3} \mathrm{H}_{7}\right)_{4} \mathrm{~N}\right]_{2} \mathrm{Hg}_{2} \mathrm{Cl}_{6}$ compound was obtained and characterised by single-crystal X-ray diffraction, infrared, and impedance spectroscopy. The latter crystallizes in the monoclinic system (space group C $2 / c, Z=8$ ) with the following unit cell dimensions: $a=18.489(1) \AA, b=13.0419(6) \AA, c=29.162(2) \AA$, and $\beta=91.686^{\circ}(2)$. Besides, its structure was solved using 84860 independent reflections leading to $R=0.038$. Electrical properties of the material were studied using impedance spectroscopic technique at different temperatures in the frequency range of $209 \mathrm{~Hz}$ to $5 \mathrm{MHz}$. Detailed analysis of the impedance spectrum suggested that the electrical properties of the material are strongly temperature-dependent. The Nyquist plots clearly showed the presence of bulk and grain boundary effect in the compound.

\section{Introduction}

The contemporary deep interest for inorganic-organic hybrid materials is due to various reasons. An obvious advantage of hybrids is that they favorably combine the properties of the organic materials to that of the inorganic one and thus to exhibit specific properties, such as electronic, optical, thermal, and catalytic [1-4]. Among halometallates (II), chloromercurates (II) have been of special interest for their structural flexibility. In fact the spherical $\mathrm{d}^{10}$ configuration of $\mathrm{Hg}^{2+}$ ion is associated with a flexible coordination environment so that the geometries of these complexes can vary from tetrahedral to octahedral and severe distortions in the ideal polyhedron occur easily, depending on crystal packing and hydrogen bonding, as well as halide dimensions [511]. In the last years, the structural and electrical properties of $\left[\left(\mathrm{C}_{3} \mathrm{H}_{7}\right)_{4} \mathrm{~N}\right]_{2} \mathrm{Cu}_{2} \mathrm{Cl}_{6}$ and $\left[\left(\mathrm{C}_{3} \mathrm{H}_{7}\right)_{4} \mathrm{~N}_{2} \mathrm{Cd}_{2} \mathrm{Cl}_{6}\right.$ compounds have been reported [12,13]. In spite of attractive properties of mercury(II) compounds in terms of their potential applications in thermometers, manometers, energy efficient fluorescent light bulbs, and mercury batteries (although somehow limited due to mercury's toxicity), we have successfully synthesized a new compound of formula $\left[\left(\mathrm{C}_{3} \mathrm{H}_{7}\right)_{4} \mathrm{~N}_{2} \mathrm{Hg}_{2} \mathrm{Cl}_{6}\right.$.

In the present paper we report on the synthesis, the structural, and spectroscopic characterizations of the $\left[\left(\mathrm{C}_{3} \mathrm{H}_{7}\right)_{4} \mathrm{~N}\right]_{2} \mathrm{Hg}_{2} \mathrm{Cl}_{6}$ compound.

\section{Experimental}

2.1. Preparation of $\left[\mathrm{N}\left(\mathrm{C}_{3} \mathrm{H}_{7}\right)_{4}\right]_{2} \mathrm{Hg}_{2} \mathrm{Cl}_{6}$. The synthesis of $\left[\mathrm{N}\left(\mathrm{C}_{3} \mathrm{H}_{7}\right)_{4}\right]_{2} \mathrm{Hg}_{2} \mathrm{Cl}_{6}$ was performed from precursors $\left[\mathrm{N}\left(\mathrm{C}_{3} \mathrm{H}_{7}\right)_{4}\right] \mathrm{Cl}$ (purity 97\%; FLUKA) and $\mathrm{HgCl}_{2}$ (purity $99.5 \%$; FLUKA). The reactions sequence for the synthesis is shown in the following equation:

$$
2\left[\mathrm{~N}\left(\mathrm{C}_{3} \mathrm{H}_{7}\right)_{4}\right] \mathrm{Cl}+2 \mathrm{HgCl}_{2} \stackrel{(1 \mathrm{M}) \mathrm{HCl}}{\longrightarrow}\left[\mathrm{N}\left(\mathrm{C}_{3} \mathrm{H}_{7}\right)_{4}\right]_{2} \mathrm{Hg}_{2} \mathrm{Cl}_{6}
$$

The solution was obtained by mixing $0.441 \mathrm{~g}$ of $\left[\mathrm{N}\left(\mathrm{C}_{3} \mathrm{H}_{7}\right)_{4}\right] \mathrm{Cl}$ and $0.218 \mathrm{~g}$ of $\mathrm{HgCl}_{2}$ in $10 \mathrm{ml}$ of $\mathrm{HCl}(1 \mathrm{M})$ aqueous solution. After few days, crystalline samples were obtained by slow evaporation at room temperature. 
TABLE 1: Summary of crystal data, X-ray diffraction intensity measurements, and refinement parameters for $\left[\mathrm{N}\left(\mathrm{C}_{3} \mathrm{H}_{7}\right)_{4}\right]_{2} \mathrm{Hg}_{2} \mathrm{Cl}_{6}$.

\begin{tabular}{|c|c|}
\hline Formula: $\left[\left(\mathrm{C}_{3} \mathrm{H}_{7}\right)_{4} \mathrm{~N}\right]_{2} \mathrm{Hg}_{2} \mathrm{Cl}_{6}$ & $\mathrm{FW}=986.6 \mathrm{~g} \cdot \mathrm{mol}^{-1}$ \\
\hline Color/shape & Colorless/prismatic \\
\hline Crystal dimensions & $0.22 \times 0.18 \times 0.11 \mathrm{~mm}$ \\
\hline Crystal system & Monoclinic \\
\hline Space group & $\mathrm{C} 2 / c\left(\mathrm{~N}^{\circ} 15\right)$ \\
\hline$a=18.489(1) \AA ̊ ., b=13.0419(6) \AA$ & $V=7409.0(7) \AA^{3}$ \\
\hline$c=29.162(2) \AA, \beta=91.686(2)$ & $Z=8, \mu=8.726 \mathrm{~mm}^{-1}$ \\
\hline Temperature $(\mathrm{K})$ & $173(2)$ \\
\hline Radiation, $\lambda(\AA)$, monochromator & Mo $K_{\alpha}, 0.71069$, graphite \\
\hline Scan angle $\left({ }^{\circ}\right)$ & $\theta-\theta$ \\
\hline$\theta$ Range $\left(^{\circ}\right)$ & $1.4-30$ \\
\hline Range of $h, k, l$ & $-26 \rightarrow 27,-16 \rightarrow 18,-40 \rightarrow 40$ \\
\hline Reflections collected/unique & $42266 / 10658\left(R_{\mathrm{int}}=0.047\right)$ \\
\hline Observed reflections $[\mathrm{Fo}>2 \sigma(\mathrm{Fo})]$ & 8486 \\
\hline Absorption correction & Multiscan (SADABS) \\
\hline$T_{\min }, T_{\max }$ & $0.542,0.823$ \\
\hline Structure resolution & Paterson methods: SHELXS-86 \\
\hline Structure refinement with & SHELXL-97 \\
\hline Refinement & $F^{2}$ full matrix \\
\hline Refined parameters & 348 \\
\hline Goodness of fit & 1.177 \\
\hline Final $R$ and $R w$ & $0.038,0.087$ \\
\hline Final $R$ and $R w$ (for all data) & $0.057,0.097$ \\
\hline Largest feature diff. map & $1.565,-1.354 \mathrm{e}^{-} / \AA^{3}$ \\
\hline$w=1 /\left[\sigma^{2}(\mathrm{Fo})^{2}+(0.035 P)^{2}+0 P\right]$ & $P=\left[\mathrm{Fo}^{2}+2 \mathrm{Fc}^{2}\right] / 3$ \\
\hline
\end{tabular}

2.2. Crystallographic Studies. Single crystals of $\left[\left(\mathrm{C}_{3} \mathrm{H}_{7}\right)_{4} \mathrm{~N}\right]_{2} \mathrm{Hg}_{2} \mathrm{Cl}_{6}$ are obtained by slow evaporation, at room temperature, of an hydrochloric acid solution containing stoichiometric amounts of $\left[\mathrm{N}\left(\mathrm{C}_{3} \mathrm{H}_{7}\right)_{4}\right] \mathrm{Cl}$ (purity 97\%; FLUKA) acidified with $\mathrm{HCl}(1 \mathrm{M})$ and $\mathrm{HgCl}_{2}$ (purity 99.5\%; FLUKA).

A single crystal with $0.2 \times 0.19 \times 0.17 \mathrm{~mm}^{3}$ dimensions was selected by optical examination. The crystal data were collected on a Siemens APEX II four-circles diffractometer using a monochromatic Mo $K_{\alpha}$ radiation $(\lambda=0.71073 \AA)$. The absorption corrections were based on multiple and symmetry-equivalent reflections in the data set using the SADABS program [14]. The structure was solved by direct methods and refined in the anisotropic approximation using SHELXS-97 [15] and SHELXL-97 [16]. The main crystal data, the parameters used for intensity data collection, and the reliability factor are gathered in Table 1 . The obtained solution permits us to localize the positions of mercury and chlorine atoms. Positions of $\mathrm{N}$ and all carbon atoms were located after subsequent Fourier series analysis. The nitrogen $\mathrm{H}$-atoms were successively located in a difference Fourier maps. The other hydrogen atoms were placed in calculated positions. Main geometrical features, bond distances, and angles are reported in Table 2 .

2.3. Infrared Spectroscopies. The infrared spectrum was recorded in the $400-4,000 \mathrm{~cm}^{-1}$ range with a Perkin-Elmer
FT-IR 1000 spectrometer using samples pressed in spectroscopically pure $\mathrm{KBr}$ pellets. Spectral resolution is better than $4 \mathrm{~cm}^{-1}$.

2.4. Impedance Spectroscopy Analysis. The finely grain samples were pressed into pellets of $8 \mathrm{~mm}$ diameter and $1.1 \mathrm{~mm}$ thickness using a hydraulic press. The pellet discs were coated with Ag paste to ensure good electrical contact. The ac impedance data, $|Z|$, and phase angle were obtained in the frequency range $209 \mathrm{~Hz}-5 \mathrm{MHz}$ using TEGAM 3550 impedance analyzer over the temperature range $293-375 \mathrm{~K}$.

\section{Results and Discussions}

3.1. Crystal Structure Description. The representations of asymmetric unit showing the ellipsoid thermal mean square displacements are represented in Figure 1. The structural arrangement of $\left[\mathrm{N}\left(\mathrm{C}_{3} \mathrm{H}_{7}\right)_{4}\right]_{2} \mathrm{Hg}_{2} \mathrm{Cl}_{6}$ is layered organization of organic-inorganic sheets staked along [010] direction, Figure 2. Each layer is translated via its neighbor by $((a+$ c)/4). The organic-inorganic layer can be described as an alternation of inorganic chain and organic double chain parallel to the [101] direction. The organic double chain is made up of two crystallographic different $\left[\mathrm{N}\left(\mathrm{C}_{3} \mathrm{H}_{7}\right)_{4}\right]^{+}$ cation, Figure 3 . Unlike the reported structure, atomic arrangement of similar compound, $\left[\mathrm{N}\left(\mathrm{C}_{3} \mathrm{H}_{7}\right)_{4}\right]_{2} \mathrm{Cu}_{2} \mathrm{Cl}_{6}$ [17] 
TABLE 2: Selected bond distances $(\AA)$ and bond angles $\left(^{\circ}\right)$ of $\left.\left[\mathrm{N}_{(} \mathrm{C}_{3} \mathrm{H}_{7}\right)_{4}\right]_{2} \mathrm{Hg}_{2} \mathrm{Cl}_{6}$ (e.s.d. are given in parentheses).

\begin{tabular}{|c|c|c|c|}
\hline \multicolumn{2}{|c|}{ Distances $(\AA)$} & \multicolumn{2}{|c|}{ Angles $\left({ }^{\circ}\right)$} \\
\hline \multicolumn{4}{|l|}{$\mathrm{Hg}(1) \mathrm{Cl}_{4}$} \\
\hline $\mathrm{Hg} 1-\mathrm{Cl}_{\mathrm{E}} 1$ & $2.387(1)$ & $\mathrm{Cl}_{\mathrm{E}} 1-\mathrm{Hg} 1-\mathrm{Cl}_{\mathrm{E}} 2$ & $133.30(6)$ \\
\hline $\mathrm{Hg} 1-\mathrm{Cl}_{\mathrm{E}} 2$ & $2.388(1)$ & $\mathrm{Cl}_{\mathrm{E}} 1-\mathrm{Hg} 1-\mathrm{Cl}_{\mathrm{L}} 1$ & $102.13(5)$ \\
\hline $\mathrm{Hg} 1-\mathrm{Cl}_{\mathrm{L}} 1$ & $2.638(1)$ & $\mathrm{Cl}_{\mathrm{E}} 1-\mathrm{Hg} 1-\mathrm{Cl}_{\mathrm{L}} 2$ & $111.83(6)$ \\
\hline \multirow[t]{3}{*}{$\mathrm{Hg} 1-\mathrm{Cl}_{\mathrm{L}} 2$} & $2.662(1)$ & $\mathrm{Cl}_{\mathrm{E}} 2-\mathrm{Hg} 1-\mathrm{Cl}_{\mathrm{L}} 1$ & $108.56(5)$ \\
\hline & & $\mathrm{Cl}_{\mathrm{E}} 2-\mathrm{Hg} 1-\mathrm{Cl}_{\mathrm{L}} 2$ & $103.25(4)$ \\
\hline & & $\mathrm{Cl}_{\mathrm{L}} 1-\mathrm{Hg} 1-\mathrm{Cl}_{\mathrm{L}} 2$ & $88.87(4)$ \\
\hline \multicolumn{4}{|l|}{$\mathrm{Hg}(2) \mathrm{Cl}_{4}$} \\
\hline $\mathrm{Hg} 2-\mathrm{Cl}_{\mathrm{E}} 3$ & $2.393(1)$ & $\mathrm{Cl}_{\mathrm{E}} 3-\mathrm{Hg} 2-\mathrm{Cl}_{\mathrm{E}} 4$ & $131.45(6)$ \\
\hline $\mathrm{Hg} 2-\mathrm{Cl}_{\mathrm{E}} 4$ & $2.399(1)$ & $\mathrm{Cl}_{\mathrm{E}} 3-\mathrm{Hg} 2-\mathrm{Cl}_{\mathrm{L}} 1$ & $101.18(5)$ \\
\hline $\mathrm{Hg} 2-\mathrm{Cl}_{\mathrm{L}} 1$ & $2.632(1)$ & $\mathrm{Cl}_{\mathrm{E}} 3-\mathrm{Hg} 2-\mathrm{Cl}_{\mathrm{L}} 2$ & $111.18(5)$ \\
\hline \multirow[t]{3}{*}{$\mathrm{Hg} 2-\mathrm{Cl}_{\mathrm{L}} 2$} & $2.659(1)$ & $\mathrm{Cl}_{\mathrm{E}} 4-\mathrm{Hg} 2-\mathrm{Cl}_{\mathrm{L}} 1$ & $109.11(5)$ \\
\hline & & $\mathrm{Cl}_{\mathrm{E}} 4-\mathrm{Hg} 2-\mathrm{Cl}_{\mathrm{L}} 2$ & $106.44(5)$ \\
\hline & & $\mathrm{Cl}_{\mathrm{L}} 1-\mathrm{Hg} 2-\mathrm{Cl}_{\mathrm{L}} 2$ & $89.07(4)$ \\
\hline \multicolumn{4}{|l|}{$\left(\mathrm{C}_{3} \mathrm{H}_{7}\right)_{4} \mathrm{~N}^{+}(1)$} \\
\hline $\mathrm{N} 1-\mathrm{C} 21$ & $1.525(5)$ & $\mathrm{C} 21-\mathrm{N} 1-\mathrm{C} 41$ & $108.2(3)$ \\
\hline $\mathrm{N} 1-\mathrm{C} 41$ & $1.524(5)$ & $\mathrm{C} 21-\mathrm{N} 1-\mathrm{C} 11$ & $108.8(3)$ \\
\hline $\mathrm{N} 1-\mathrm{C} 11$ & $1.527(5)$ & $\mathrm{C} 41-\mathrm{N} 1-\mathrm{C} 11$ & $111.9(3)$ \\
\hline $\mathrm{N} 1-\mathrm{C} 31$ & $1.531(6)$ & $\mathrm{C} 21-\mathrm{N} 1-\mathrm{C} 31$ & $111.6(3)$ \\
\hline $\mathrm{C} 11-\mathrm{C} 12$ & $1.524(7)$ & $\mathrm{C} 41-\mathrm{N} 1-\mathrm{C} 31$ & $108.6(3)$ \\
\hline $\mathrm{C} 12-\mathrm{C} 13$ & $1.528(7)$ & $\mathrm{C} 11-\mathrm{N} 1-\mathrm{C} 31$ & $107.8(3)$ \\
\hline $\mathrm{C} 21-\mathrm{C} 22$ & $1.522(7)$ & $\mathrm{C} 12-\mathrm{C} 11-\mathrm{N} 1$ & $116.4(4)$ \\
\hline $\mathrm{C} 22-\mathrm{C} 23$ & $1.510(7)$ & $\mathrm{C} 11-\mathrm{C} 12-\mathrm{C} 13$ & $108.9(4)$ \\
\hline C31-C32 & $1.520(7)$ & $\mathrm{C} 22-\mathrm{C} 21-\mathrm{N} 1$ & $116.3(4)$ \\
\hline C32-C33 & $1.521(7)$ & $\mathrm{C} 23-\mathrm{C} 22-\mathrm{C} 21$ & $109.8(4)$ \\
\hline $\mathrm{C} 41-\mathrm{C} 42$ & $1.521(6)$ & $\mathrm{C} 32-\mathrm{C} 31-\mathrm{N} 1$ & $115.6(3)$ \\
\hline \multirow[t]{3}{*}{$\mathrm{C} 42-\mathrm{C} 43$} & $1.535(7)$ & $\mathrm{C} 33-\mathrm{C} 32-\mathrm{C} 31$ & $109.0(4)$ \\
\hline & & $\mathrm{C} 42-\mathrm{C} 41-\mathrm{N} 1$ & $116.8(4)$ \\
\hline & & $\mathrm{C} 41-\mathrm{C} 42-\mathrm{C} 43$ & $108.7(4)$ \\
\hline \multicolumn{4}{|l|}{$\left(\mathrm{C}_{3} \mathrm{H}_{7}\right)_{4} \mathrm{~N}^{+}(2)$} \\
\hline $\mathrm{N} 2-\mathrm{C} 81$ & $1.519(5)$ & $\mathrm{C} 81-\mathrm{N} 2-\mathrm{C} 51$ & $111.1(3)$ \\
\hline $\mathrm{N} 2-\mathrm{C} 51$ & $1.522(6)$ & $\mathrm{C} 81-\mathrm{N} 2-\mathrm{C} 61$ & $108.6(3)$ \\
\hline $\mathrm{N} 2-\mathrm{C} 61$ & $1.524(6)$ & $\mathrm{C} 51-\mathrm{N} 2-\mathrm{C} 61$ & $109.9(3)$ \\
\hline $\mathrm{N} 2-\mathrm{C} 71$ & $1.532(6)$ & $\mathrm{C} 81-\mathrm{N} 2-\mathrm{C} 71$ & $108.9(3)$ \\
\hline C51-C52 & $1.534(7)$ & $\mathrm{C} 51-\mathrm{N} 2-\mathrm{C} 71$ & $107.7(3)$ \\
\hline C52-C53 & $1.520(7)$ & $\mathrm{C} 61-\mathrm{N} 2-\mathrm{C} 71$ & $110.8(3)$ \\
\hline C61-C62 & $1.515(6)$ & $\mathrm{N} 2-\mathrm{C} 51-\mathrm{C} 52$ & $116.1(4)$ \\
\hline C62-C63 & $1.524(7)$ & $\mathrm{C} 53-\mathrm{C} 52-\mathrm{C} 51$ & $110.6(4)$ \\
\hline C71-C72 & $1.512(7)$ & C62-C61-N2 & $116.3(4)$ \\
\hline C72-C73 & $1.531(7)$ & C61-C62-C63 & $108.5(4)$ \\
\hline C81-C82 & $1.531(7)$ & $\mathrm{C} 72-\mathrm{C} 71-\mathrm{N} 2$ & $116.8(4)$ \\
\hline \multirow[t]{3}{*}{ C82-C83 } & $1.532(7)$ & C71-C72-C73 & $107.9(4)$ \\
\hline & & N2-C81-C82 & $115.2(4)$ \\
\hline & & C81-C82-C83 & $108.7(4)$ \\
\hline
\end{tabular}



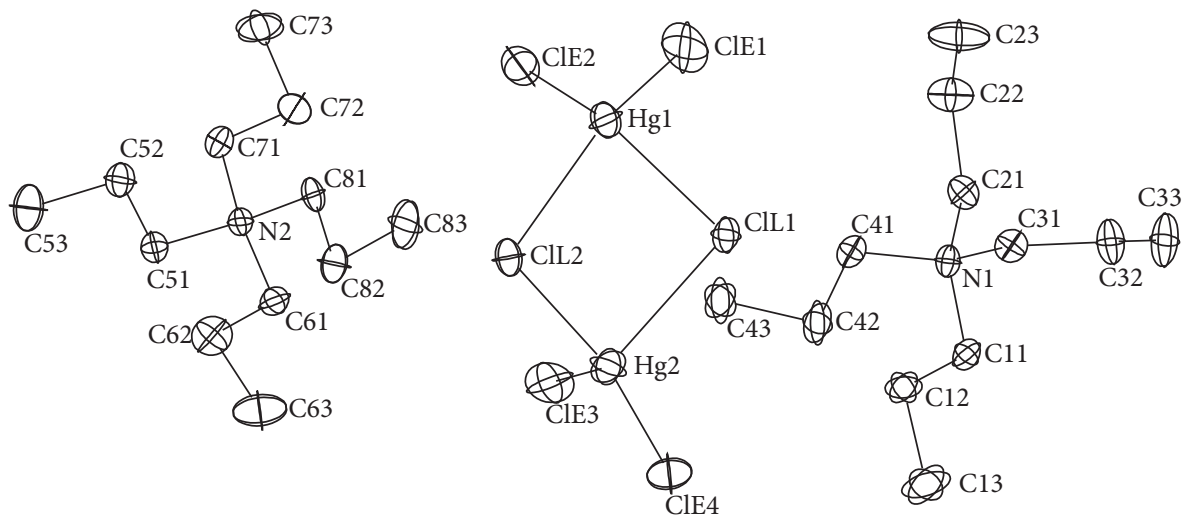

FIGURE 1: Representation of the ellipsoid of thermal mean square displacements of nonhydrogen atoms at $50 \%$ of the asymmetric unit.

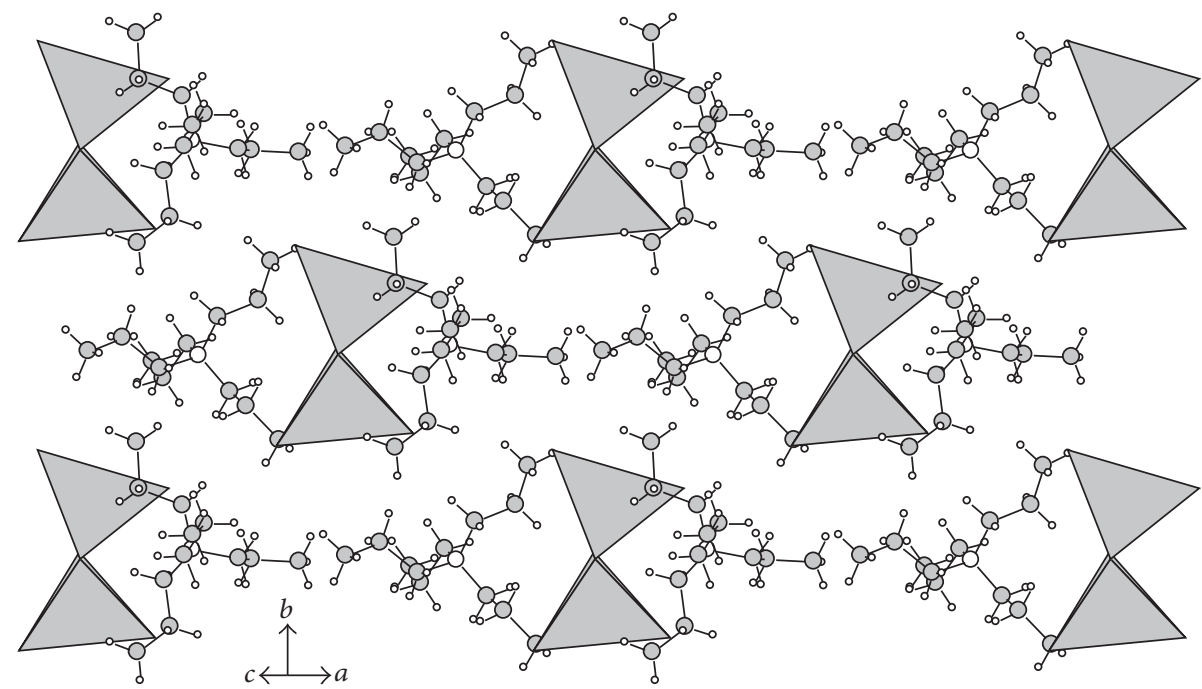

FIGURE 2: [101] view showing the organic-inorganic layers staked along $b$ direction; $\mathrm{Hg}_{2} \mathrm{Cl}_{6}$ schematized by grey tetrahedra, grate empty, and small and full circles represent nitrogen, hydrogen, and carbon atoms, respectively.

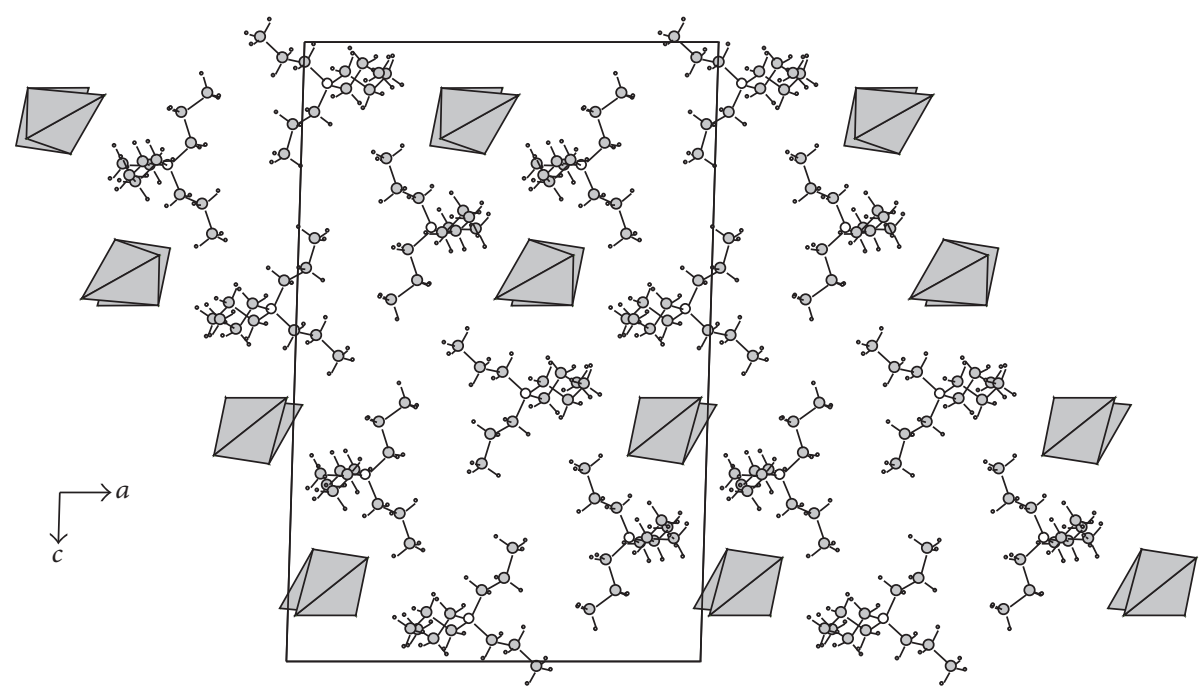

Figure 3: View of an organic-inorganic layer of $\left[\mathrm{N}\left(\mathrm{C}_{3} \mathrm{H}_{7}\right)_{4}\right]_{2} \mathrm{Hg}_{2} \mathrm{Cl}_{6}$. 


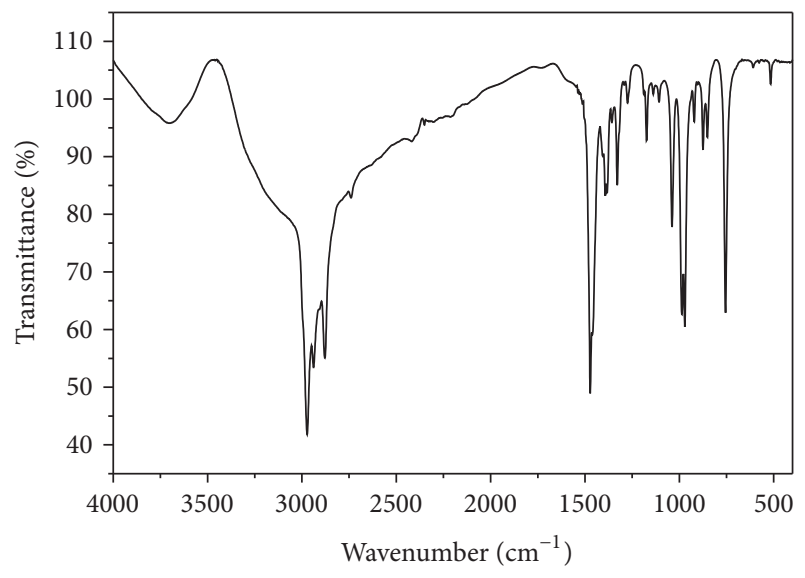

FIGURE 4: Infrared spectrum of the $\left[\mathrm{N}\left(\mathrm{C}_{3} \mathrm{H}_{7}\right)_{4}\right]_{2} \mathrm{Hg}_{2} \mathrm{Cl}_{6}$ compound at room temperature.

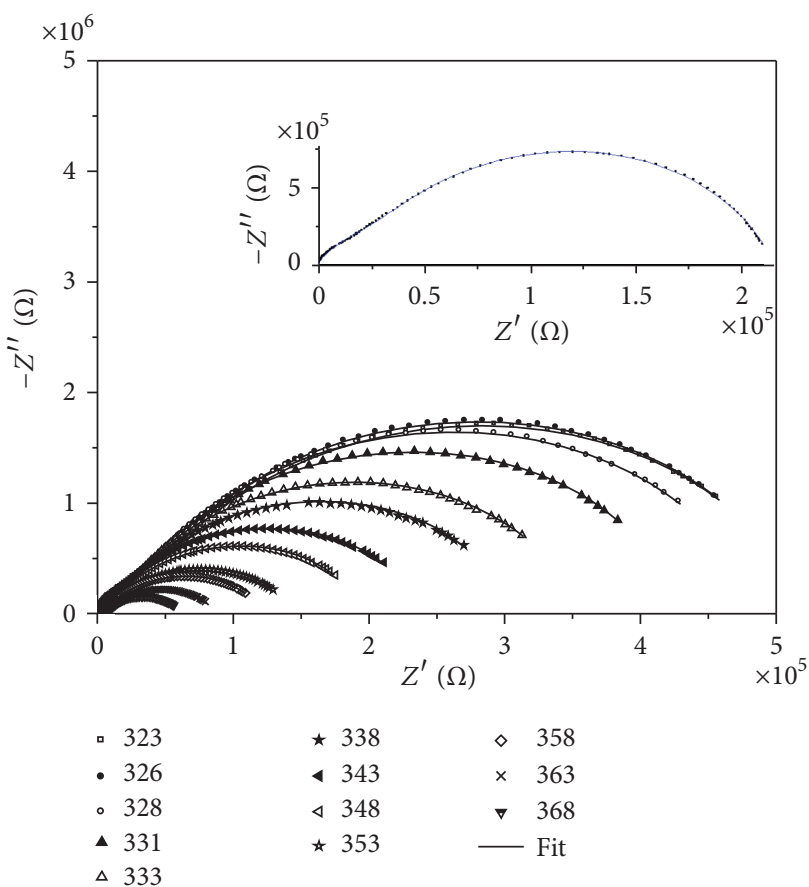

Figure 5: Impedance spectra of $\left[\left(\mathrm{C}_{3} \mathrm{H}_{7}\right)_{4} \mathrm{~N}\right]_{2} \mathrm{Hg}_{2} \mathrm{Cl}_{6}$ sample at different temperature. The inset shows the plot of $\left(-Z^{\prime \prime}\right)$ versus $Z^{\prime}$ at $338 \mathrm{~K}$.

and $\left[\mathrm{N}\left(\mathrm{C}_{3} \mathrm{H}_{7}\right)_{4}\right]_{2} \mathrm{Cd}_{2} \mathrm{Cl}_{6}[13]$, can be described as a sequence of alternating organic-inorganic layers. In the organic layer, $\mathrm{N}\left(\mathrm{C}_{3} \mathrm{H}_{7}\right)_{4}$ groups orient their aliphatic chains parallel to organic sheets. For $\left[\mathrm{N}\left(\mathrm{C}_{3} \mathrm{H}_{7}\right)_{4}\right]_{2} \mathrm{Hg}_{2} \mathrm{Cl}_{6}$ structure, the alkylammonium cation shows a tetrahedral environment. However, each $\left(\mathrm{C}_{3} \mathrm{H}_{7}\right)_{4}$ fragment develops along the $\mathrm{N}-\mathrm{C}$ direction of the $\mathrm{NC}_{4}$ tetrahedra. Consequently, each two fragments made a " $V$ " shape and were observed in the same plane. Plans contain all $\left(\mathrm{C}_{3} \mathrm{H}_{7}\right)_{4}$ are perpendicular. Two

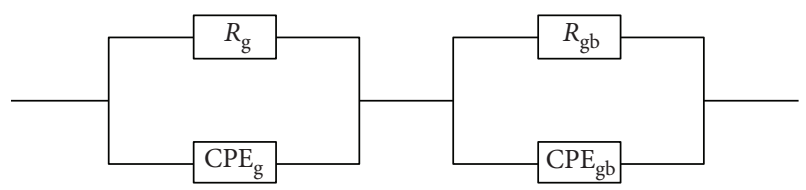

FIGURE 6: Equivalent circuit model of the $\left[\left(\mathrm{C}_{3} \mathrm{H}_{7}\right)_{4} \mathrm{~N}\right]_{2} \mathrm{Hg}_{2} \mathrm{Cl}_{6}$ compound.

$\left(\mathrm{C}_{3} \mathrm{H}_{7}\right)_{4}$ chains are observed in the plane of the organicinorganic layer. The other fragments, localized in the plan perpendicular to layer, are oriented in both sides of the inorganic chain. Both cations have $\mathrm{C} 1$ point group symmetry. $\mathrm{C}-\mathrm{C}-\mathrm{C}, \mathrm{C}-\mathrm{N}-\mathrm{C}$ and $\mathrm{N}-\mathrm{C}-\mathrm{C}$ angles and $\mathrm{C}-\mathrm{C}$ and $\mathrm{C}-\mathrm{N}$ distances, Table 2, are commonly observed [17].

The inorganic chain is made up of one $\mathrm{Hg}_{2} \mathrm{Cl}_{6}$ dimers. The anion is built up by two independent $\mathrm{HgCl}_{4}$ tetrahedra and shares one bridging chlorine atoms $\left(\mathrm{Cl}_{\mathrm{L}} 1\right.$ and $\left.\mathrm{Cl}_{\mathrm{L}} 2\right)$ as shown in Figure 1. The $\mathrm{Hg}_{2} \mathrm{Cl}_{6}$ dimers can be described as two strongly distorted $\mathrm{HgCl}_{4}$ tetrahedra. The $\mathrm{Hg}_{2} \mathrm{Cl}_{6}$ tetrahedron presents a $\mathrm{C} 1$ punctual symmetry. The $\mathrm{M}_{2} \mathrm{X}_{6}$ groups are commonly observed in this family. Two types of ligands are usually mentioned, $\mathrm{X}_{\mathrm{E}}$ (external) and $X_{\mathrm{L}}$ (linkage). Moreover, bibliographic investigations show that $\mathrm{M}-\mathrm{X}$ distances and $\mathrm{X}-\mathrm{M}-\mathrm{X}$ angles verify $\left(\mathrm{M}-\mathrm{X}_{\mathrm{L}}>\mathrm{M}-\mathrm{X}_{\mathrm{E}}\right)$ (I) and $\left(\mathrm{X}_{\mathrm{L}}-\mathrm{M}-\mathrm{X}_{\mathrm{E}}\right.$ and $\mathrm{X}_{\mathrm{E}}-\mathrm{M}-\mathrm{X}_{\mathrm{E}}$ are generally bigger than $\mathrm{X}_{\mathrm{L}}-\mathrm{M}-\mathrm{X}_{\mathrm{L}}$ ) (II) $[18,19]$. The geometry of $\mathrm{Hg}_{2} \mathrm{Cl}_{6}$ dimers verifies the reported relations, Table 2. The $\mathrm{Hg}_{2} \mathrm{Cl}_{6}{ }^{2-}$ anion, $\mathrm{Cl}_{\mathrm{L}}-\mathrm{Hg}-\mathrm{Cl}_{\mathrm{L}}-\mathrm{Hg}$, is pseudosquare. These results are in agreement with the above comparison (I and II).

3.2. Infrared Spectra. The infrared spectrum of the $\left[\mathrm{N}\left(\mathrm{C}_{3} \mathrm{H}_{7}\right)_{4}\right]_{2} \mathrm{Hg}_{2} \mathrm{Cl}_{6}$ compound at room temperature is shown in Figure 4. A detailed assignment of most important bands is realized by comparison with similar compounds [20-27]. The wavenumbers and proposed band assignments are listed in Table 3.

The principal bands are assigned to the internal modes of the propyl group: strong absorption band appears near $2972 \mathrm{~cm}^{-1}$ which was assigned to the asymmetric methyl stretching mode $v_{\text {as }}\left(\mathrm{CH}_{3}\right)$. Two bands are observed at 2940 and $2878 \mathrm{~cm}^{-1}$, which were assigned to the $v_{\mathrm{as}}\left(\mathrm{CH}_{2}\right)$ and $v_{\mathrm{s}}\left(\mathrm{CH}_{2}\right)$ stretching modes, respectively. A strong absorption band appears near $1458 \mathrm{~cm}^{-1}$ which was assigned to the asymmetric methyl deformation mode $\delta_{\text {as }}\left(\mathrm{CH}_{3}\right)$. Another band, assigned to the symmetric methyl $\delta_{\mathrm{s}}\left(\mathrm{CH}_{3}\right)$ deformation modes, was observed near $1357 \mathrm{~cm}^{-1}$. The splitting $(\mathrm{C}-\mathrm{C}-\mathrm{C}-\mathrm{N})$ bending mode at $1138 \mathrm{~cm}^{-1}$ may correspond to different conformers of the organic chains. The bands observed around $968 \mathrm{~cm}^{-1}$ were assigned to $v_{1}\left(\mathrm{NC}_{4}\right)$ stretching modes. A weak band which appeared at $874 \mathrm{~cm}^{-1}$ is related to the $\rho_{r}\left(\mathrm{CH}_{3}\right)+\rho_{r}\left(\mathrm{CH}_{2}\right)$ rocking vibration mode, while the deformation mode $v_{3}\left(\mathrm{NC}_{4}\right)$ appears below $755 \mathrm{~cm}^{-1}$. 


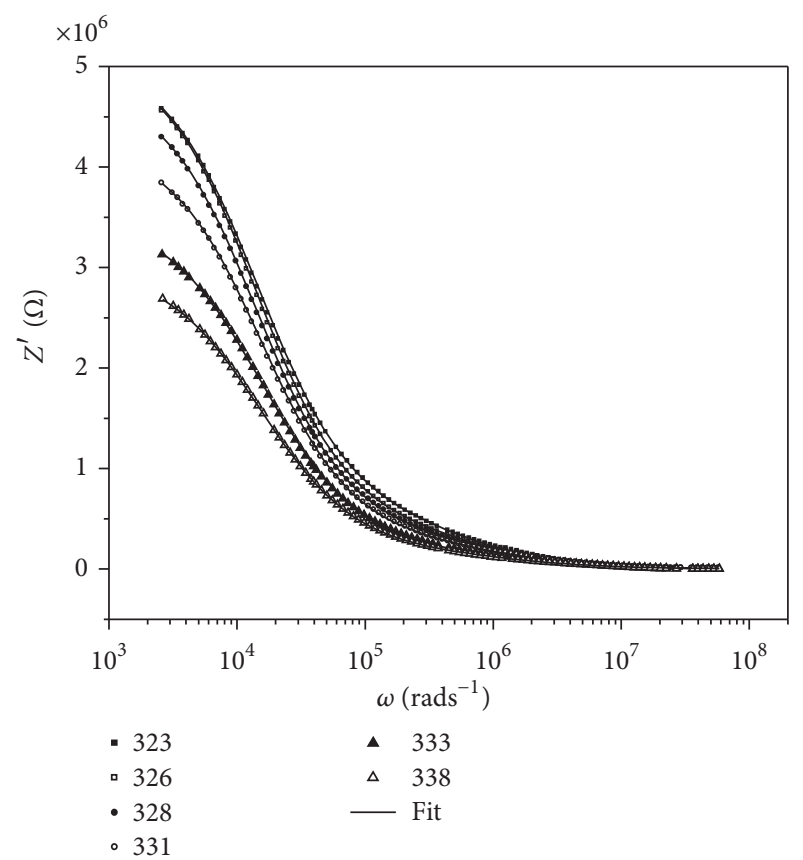

(a)

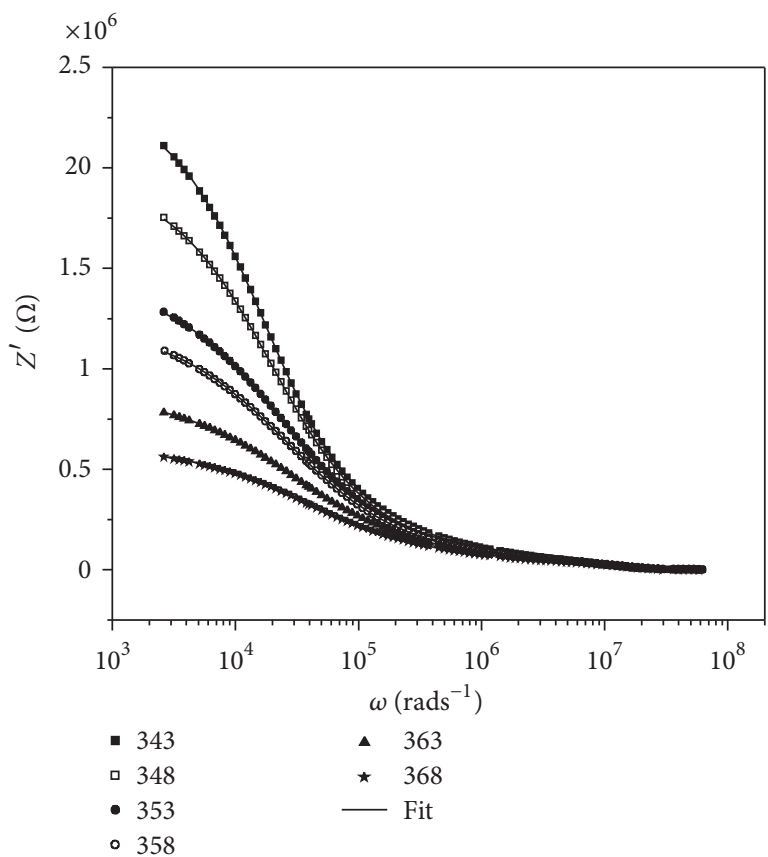

(b)

FIGURE 7: Frequency dependence of real part of impedance of $\left[\left(\mathrm{C}_{3} \mathrm{H}_{7}\right)_{4} \mathrm{~N}\right]_{2} \mathrm{Hg}_{2} \mathrm{Cl}_{6}$ at different temperatures.

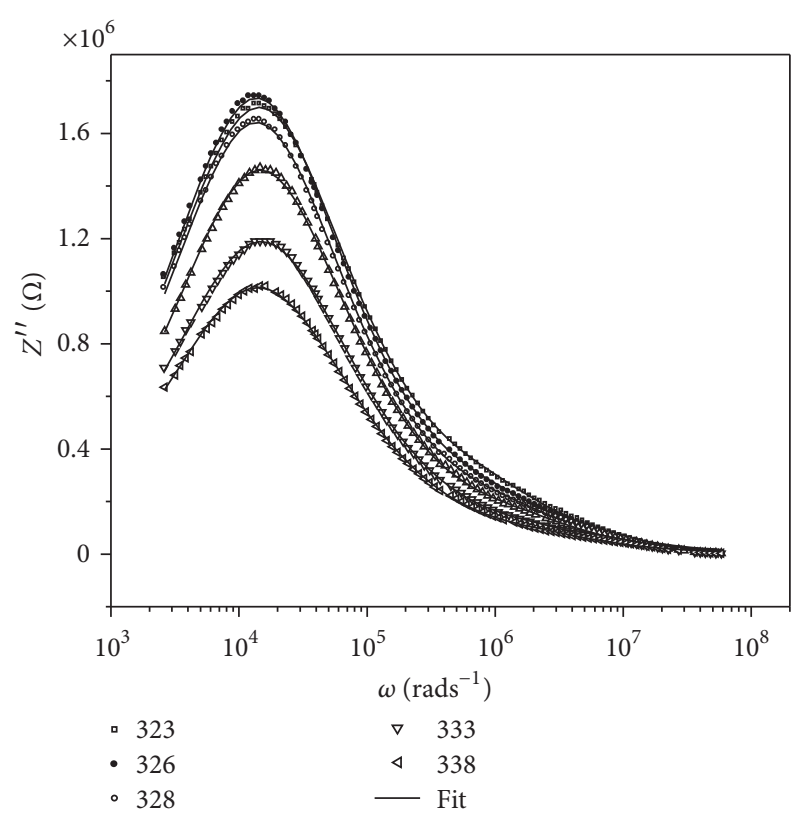

(a)

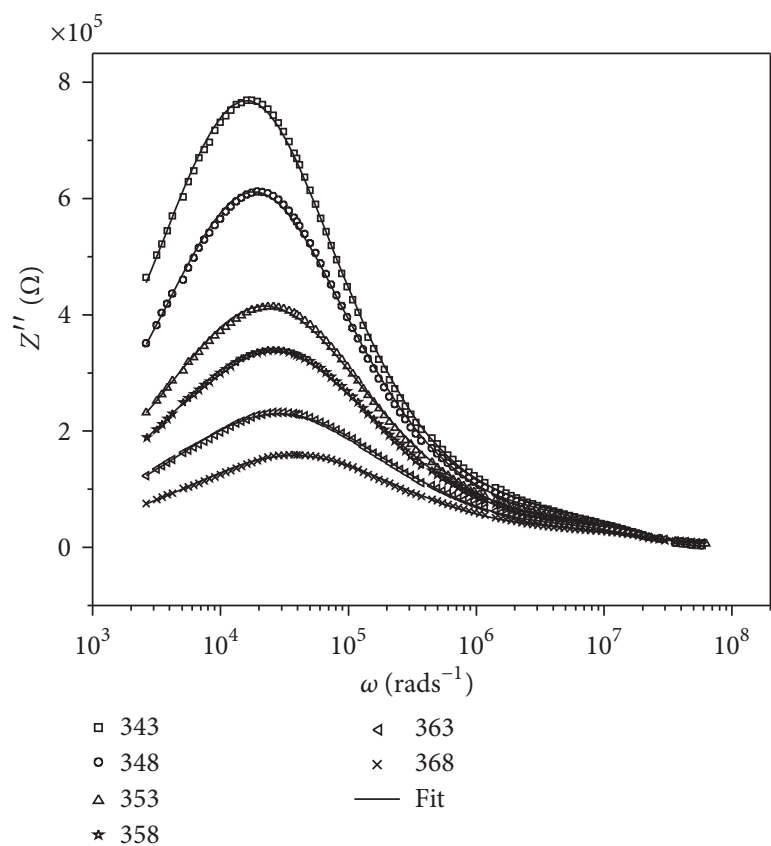

(b)

FIGURE 8: Frequency dependence of imaginary part of impedance of $\left[\left(\mathrm{C}_{3} \mathrm{H}_{7}\right)_{4} \mathrm{~N}\right]_{2} \mathrm{Hg}_{2} \mathrm{Cl}_{6}$ at different temperatures.

\subsection{Electrical Properties}

3.3.1. Impedance Studies. Impedance spectroscopy is a useful method to resolve the contributions of various processes such as bulk, grain boundary, and electrode effect in the specified frequency domain. In addition, the resistance and the capacitance associated with the solids could be estimated using impedance spectroscopy. 


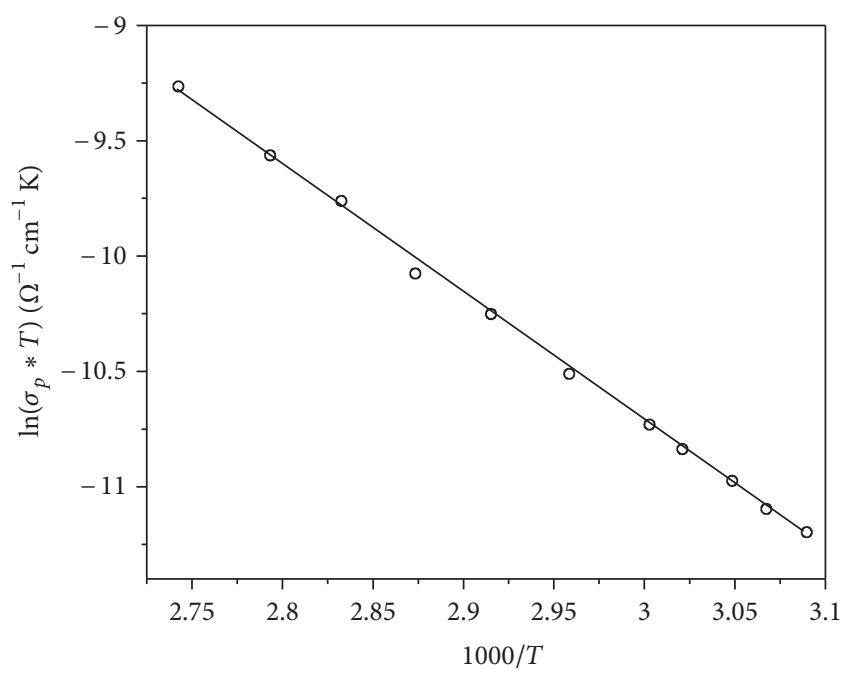

Figure 9: Temperature dependence of $\operatorname{Ln}\left(\sigma_{p} T\right)$ versus reciprocal temperature for $\left[\mathrm{N}\left(\mathrm{C}_{3} \mathrm{H}_{7}\right)_{4}\right]_{2} \mathrm{Cu}_{2} \mathrm{Cl}_{6}$.

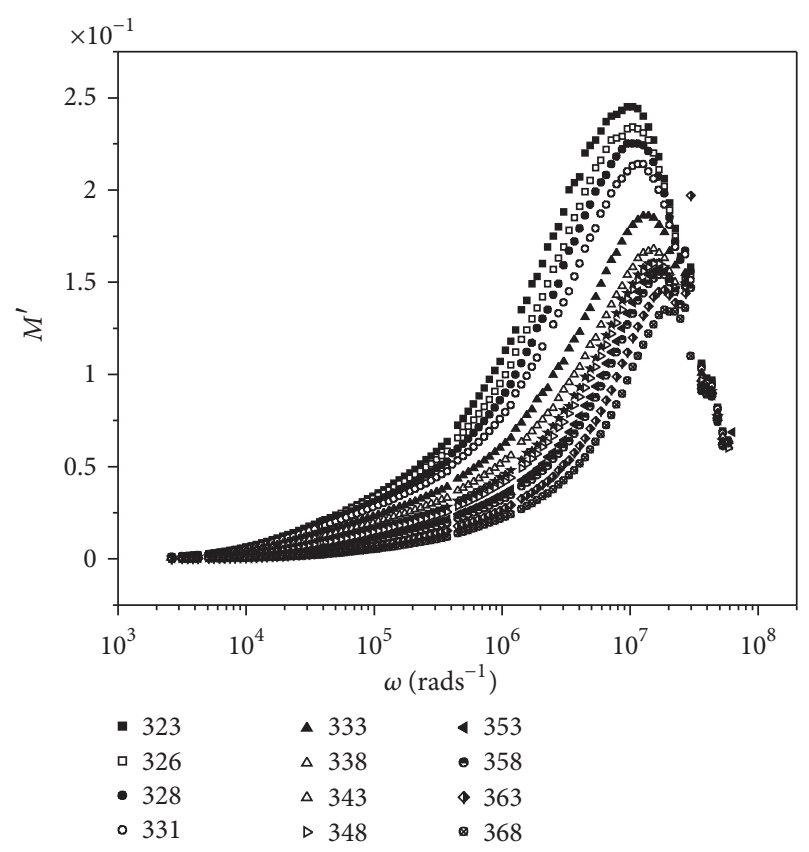

FIGURE 10: Variation of real part of electric modulus $\left(M^{\prime}\right)$ with frequency for $\left[\left(\mathrm{C}_{3} \mathrm{H}_{7}\right)_{4} \mathrm{~N}\right]_{2} \mathrm{Hg}_{2} \mathrm{Cl}_{6}$ at several temperatures.

Figure 5 shows the plot of $\left(-Z^{\prime \prime}\right)$ versus $Z^{\prime}$ taken over the frequency range $(209 \mathrm{~Hz}$ to $5 \mathrm{MHz}$ ) at different temperatures $(293 \mathrm{~K} \leq T \leq 375 \mathrm{~K})$. The inset in Figure 5 shows the plot of $\left(-Z^{\prime \prime}\right)$ versus $Z^{\prime}$ at $338 \mathrm{~K}$.

Two arcs are obtained which may be ascribed to the circuit shown in Figure 6 where $R_{\mathrm{gb}}$ and $\mathrm{CPE}_{\mathrm{gb}}$, are respectively, the resistance and the constant phase elements arising out from the grain boundaries response of the sample showed by the second arc observed at low frequency, while $R_{\mathrm{b}}$ and $\mathrm{CPE}_{\mathrm{b}}$ are, respectively, the resistance and the constant phase elements due to the bulk response of the compound showed by the first arc observed at high frequency [28-30].
The impedance of CPE is $Z_{\mathrm{CPE}}=1 / Q(j \omega)^{\alpha}$. Usually $Z_{\mathrm{CPE}}$ is considered to be a dispersive capacitance. $\alpha$ is the measure of the capacitive nature of the element: if $\alpha=1$ the element is an ideal capacitor, if $\alpha=0$ it behaves as a frequency independent ohmic resistor, whereas if $\alpha=-1$ it behaves as an inductance. (Note that there are known cases when $Z_{\mathrm{CPE}}$ cannot be treated this way; e.g., the Warburg impedance, which is connected with diffusion, is a CPE element with $\alpha=0.5$.)

The real and the imaginary components of the whole impedance of this circuit were calculated according to the following expressions:

$$
\begin{aligned}
Z^{\prime} & \\
= & \frac{R_{\mathrm{b}}^{2} Q_{\mathrm{b}} \omega^{\alpha_{b}} \cos \left(\alpha_{\mathrm{b}} \pi / 2\right)+R_{\mathrm{b}}}{\left(1+R_{\mathrm{b}} Q_{\mathrm{b}} \omega^{\alpha_{\mathrm{b}}} \cos \left(\alpha_{\mathrm{b}} \pi / 2\right)\right)^{2}+\left(R_{\mathrm{b}} Q_{\mathrm{b}} \omega^{\alpha_{\mathrm{b}}} \sin \left(\alpha_{\mathrm{b}} \pi / 2\right)\right)^{2}} \\
& +\frac{R_{\mathrm{gb}}^{2} Q_{\mathrm{gb}} \omega^{\alpha_{\mathrm{gb}}} \cos \left(\alpha_{\mathrm{gb}} \pi / 2\right)+R_{\mathrm{gb}}}{\left(1+R_{\mathrm{gb}} Q_{\mathrm{gb}} \omega^{\alpha_{\mathrm{gb}}} \cos \left(\alpha_{\mathrm{gb}} \pi / 2\right)\right)^{2}+\left(R_{\mathrm{gb}} \mathrm{Q}^{\alpha_{\mathrm{gb}}} \sin \left(\alpha_{\mathrm{gb}} \pi / 2\right)\right)^{2}}
\end{aligned}
$$

$$
\begin{aligned}
& -Z^{\prime \prime} \\
& =\frac{R_{\mathrm{b}}^{2} Q_{\mathrm{b}} \omega^{\alpha_{\mathrm{b}}} \sin \left(\alpha_{\mathrm{b}} \pi / 2\right)}{\left(1+R_{\mathrm{b}} Q_{\mathrm{b}} \omega^{\alpha_{\mathrm{b}}} \cos \left(\alpha_{\mathrm{b}} \pi / 2\right)\right)^{2}+\left(R_{\mathrm{b}} Q_{\mathrm{b}} \omega^{\alpha_{\mathrm{b}}} \sin \left(\alpha_{\mathrm{b}} \pi / 2\right)\right)^{2}} \\
& +\frac{R_{\mathrm{gb}}^{2} Q_{\mathrm{gb}} \omega^{\alpha_{\mathrm{gb}}} \sin \left(\alpha_{\mathrm{gb}} \pi / 2\right)}{\left(1+R_{\mathrm{gb}} Q_{\mathrm{gb}} \omega^{\alpha_{\mathrm{gb}}} \cos \left(\alpha_{\mathrm{gb}} \pi / 2\right)\right)^{2}+\left(R_{\mathrm{gb}} \mathrm{Q}_{\mathrm{gb}} \omega^{\alpha_{\mathrm{gb}}} \sin \left(\alpha_{\mathrm{gb}} \pi / 2\right)\right)^{2}}
\end{aligned}
$$

The curves of $Z^{\prime}$ and $-Z^{\prime \prime}$ versus frequency at several temperatures are fitted by (2) and (3), respectively. Figures 7 and 8 represent $Z^{\prime}$ and $-Z^{\prime \prime}$ versus frequency at several temperatures together with fits to the equivalent circuit represented in Figure 6. All fitted curves at each temperature show the good conformity of calculated lines with the experimental data indicating that the suggested equivalent circuit describes the crystal-electrolyte interface reasonably well.

The temperature dependences of the fitted parameters $R_{\mathrm{b}}$, $R_{\mathrm{gb}}, \mathrm{Q}_{\mathrm{b}}, \mathrm{Q}_{\mathrm{gb}}, \alpha_{\mathrm{b}}$, and $\alpha_{\mathrm{gb}}$ are given in Table 4 . As temperature decreases, the grain boundaries resistance $R_{\mathrm{gb}}$ increases with the arc increasing. The bulk resistance $R_{\mathrm{b}}$ increases as temperature decreases as is expected for an activated conduction mechanism that is reflected as an increase in the radius of the arc as temperature is lowered.

The variation of fitted parameters $\alpha_{\mathrm{b}}$ versus temperature (0.77< $<<0.97)$ shows that the constant phase elements (CPE) represents a leaking (non ideal) capacitor as it contains both imaginary and real parts and constitutes energy dissipation because of the presence of the impedance real part.

The capacitance values (Q) of the equivalent circuit element are critical to the identification of the grain boundary and grain interior contribution. It has already been established in the literatures that the dispersion in the grain boundaries and in the bulk has a capacitance value in the range of $\mathrm{nF}$ and $\mathrm{pF}$, respectively. In our case the capacitance 
TABLE 3: Observed IR frequencies $\left(\right.$ in $\left.\mathrm{cm}^{-1}\right)$ for $\left[\mathrm{N}\left(\mathrm{C}_{3} \mathrm{H}_{7}\right)_{4}\right]_{2} \mathrm{Hg}_{2} \mathrm{Cl}_{6}$ at room temperature.

\begin{tabular}{|c|c|}
\hline IR wavenumbers $\left(\mathrm{cm}^{-1}\right)$ & Assignment \\
\hline \multicolumn{2}{|l|}{516} \\
\hline \multicolumn{2}{|l|}{609} \\
\hline 755 & $v_{3}\left(\mathrm{NC}_{4}\right)$ \\
\hline 851 & $\rho_{r}\left(\mathrm{CH}_{2}\right)$ \\
\hline 874 & $\rho_{r}\left(\mathrm{CH}_{3}\right)+\rho_{r}\left(\mathrm{CH}_{2}\right)$ \\
\hline 920 & $\rho_{r}\left(\mathrm{CH}_{2}\right)$ \\
\hline 968 & $v_{1}\left(\mathrm{NC}_{4}\right)$ \\
\hline 986 & $v_{\mathrm{as}}(\mathrm{C}-\mathrm{C})$ \\
\hline 1038 & $\nu_{s}(\mathrm{C}-\mathrm{C}-\mathrm{N})$ \\
\hline \multicolumn{2}{|l|}{1107} \\
\hline 1138 & $\nu_{s}(\mathrm{C}-\mathrm{C}-\mathrm{C}-\mathrm{N})$ \\
\hline \multicolumn{2}{|l|}{1173} \\
\hline 1274 & $\tau\left(\mathrm{CH}_{2}\right)$ \\
\hline 1328 & $\omega\left(\mathrm{CH}_{2}\right)$ \\
\hline 1357 & $\delta_{\mathrm{s}}\left(\mathrm{CH}_{3}\right)$ \\
\hline \multicolumn{2}{|l|}{1392} \\
\hline 1458 & $\delta_{\mathrm{as}}\left(\mathrm{CH}_{3}\right)$ \\
\hline \multicolumn{2}{|l|}{1471} \\
\hline \multicolumn{2}{|l|}{2413} \\
\hline \multicolumn{2}{|l|}{2734} \\
\hline 2878 & $v_{\mathrm{s}}\left(\mathrm{CH}_{2}\right)$ \\
\hline 2940 & $v_{\mathrm{as}}\left(\mathrm{CH}_{2}\right)$ \\
\hline 2972 & $v_{\mathrm{as}}\left(\mathrm{CH}_{3}\right)$ \\
\hline 3701 & \\
\hline
\end{tabular}

values $\left(Q_{\mathrm{b}}\right)$ vary between $1.05 \mathrm{pF}$ and $89.2 \mathrm{pF}$ and $Q_{\mathrm{gb}}$ vary in the range $1.42 \mathrm{nF}-22.7 \mathrm{nF}$. This implies that the first arc response is due to grain interiors response and the second arc arising out from the grain boundaries response.

The temperature dependence of the conductivity obtained from the fits of the first arc observed at high frequency is shown in Figure 9. It is noted that the variation of the conductivity with temperature obeys an Arrhenius equation as follows:

$$
\sigma_{p}=\frac{A}{T} \exp \left(\frac{E_{b}}{K_{\beta} T}\right)
$$

where $\sigma_{p}$ is the conductivity at temperature $T, A$ the preexponential factor, $K_{\beta}$ the Boltzmann's constant, and $E_{b}$ is the thermal activation energy. The value of the activation energy $E_{b}$ is about $0.46 \mathrm{eV}$ obtained from the least squares straight line fits.

3.3.2. Modulus Studies. The modulus formalisma is particularly suitable to extract phenomena such as electrode polarization and conductivity relaxation times [31,32].

Consider the following:

$$
M^{*}=\frac{1}{\varepsilon^{*}}=j \omega C_{0} Z^{*}(\omega)=M^{\prime}(\omega)+j M^{\prime \prime}(\omega) .
$$

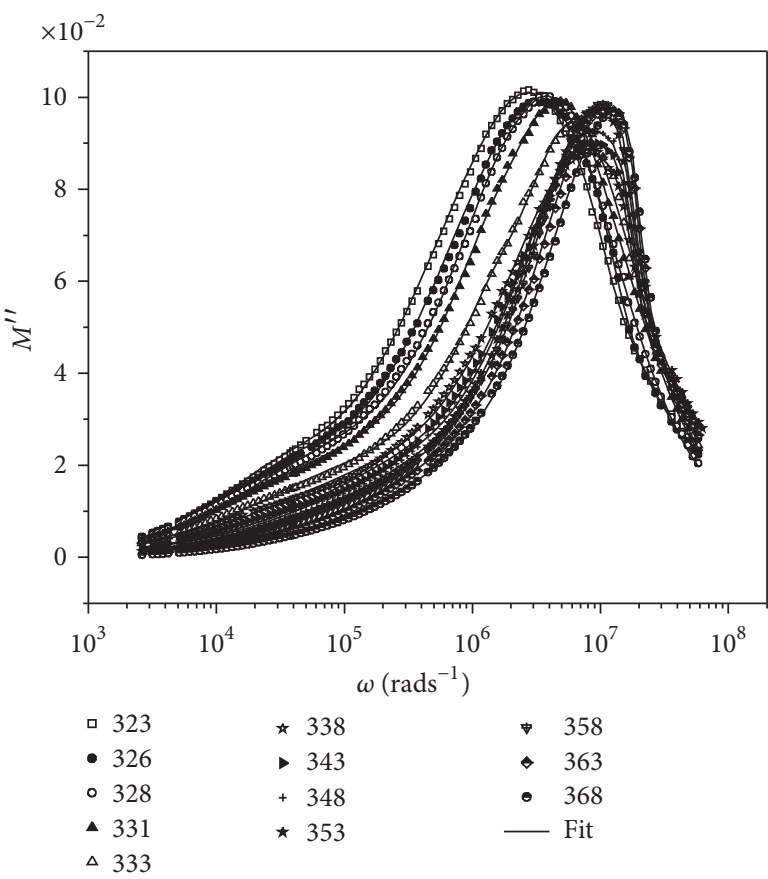

FIGURE 11: Variation of imaginary part of modulus $\left(M^{\prime \prime}\right)$ with frequency for $\left[\left(\mathrm{C}_{3} \mathrm{H}_{7}\right)_{4} \mathrm{~N}\right]_{2} \mathrm{Hg}_{2} \mathrm{Cl}_{6}$ at different temperatures.

The dependence of electric modulus on frequency can be written also as [33]:

$$
M=M s\left[1-\int_{0}^{\infty} e^{-j \omega t}\left(-\frac{d \varphi(t)}{d t}\right) d t\right]=M s[1-\varphi(\omega)],
$$

where $\varphi(t)$ gives the time evolution of the electric field with in the dielectric.

Figure 10 shows the variation of $M^{\prime}$ as a function of frequency at various temperatures. At lower frequencies, $M^{\prime}$ tends to be very small, confirming that the electrode effects make a negligible contribution and hence may be ignored when the data are analyzed in modulus formalism. $M^{\prime}$ attains a maximum below $10^{7} \mathrm{~Hz}$ and decrease above for all temperatures. The decreases of $M^{\prime}$ above $10^{7} \mathrm{~Hz}$ may be interpreted as the accumulation of charges at the interface between the sample and the electrode, that is, space charge polarization $[34,35]$.

Figure 11 shows the temperature-frequency dependence of imaginary part of electric modulus $\left(M^{\prime \prime}\right)$. The asymmetric modulus peaks shifts towards higher frequency side indicating correlation between motions of mobile ions charges [36]. The asymmetry in peak broadening shows the spread of relaxation times with different time constant, and hence relaxation is of non-Debye type. The existence of low frequency peaks suggests that the ions can move over long distances whereas high-frequency peaks suggest confinement of ions in their potential well. The peak in the $M^{\prime \prime}$ plot shifts toward higher frequencies with increase in temperature and also the peak height increases. This reveals that when the frequency is high, 
TABLE 4: Fitting parameter obtained from impedance spectroscopy at different temperature ranges.

\begin{tabular}{|c|c|c|c|c|c|c|}
\hline$T(\mathrm{~K})$ & $R_{\mathrm{gb}}(\mathrm{M} \Omega)$ & $Q_{g b}\left(10^{-9} F\right)$ & $\alpha_{\mathrm{gb}}$ & $R_{\mathrm{b}}(\mathrm{M} \Omega)$ & $Q_{b}\left(10^{-12} F\right)$ & $\alpha_{\mathrm{b}}$ \\
\hline 323 & 5.12 & 1.57 & 0.745 & 2.64 & 12.2 & 0.77 \\
\hline 326 & 5.10 & 1.42 & 0.759 & 2.24 & 21.8 & 0.78 \\
\hline 328 & 4.82 & 1.47 & 0.761 & 1.87 & 28.0 & 0.78 \\
\hline 331 & 4.26 & 1.53 & 0.764 & 1.47 & 34.2 & 0.82 \\
\hline 333 & 3.56 & 2.07 & 0.751 & 0.853 & 34.7 & 0.83 \\
\hline 338 & 3.09 & 2.77 & 0.739 & 0.689 & 38.5 & 0.87 \\
\hline 343 & 2.40 & 3.74 & 0.725 & 0.531 & 61.9 & 0.89 \\
\hline 348 & 1.98 & 4.98 & 0.705 & 0.407 & 67.8 & 0.91 \\
\hline 353 & 1.44 & 8.86 & 0.665 & 0.255 & 88.7 & 0.92 \\
\hline 358 & 1.22 & 11.8 & 0.647 & 0.221 & 89.2 & 0.95 \\
\hline 363 & 0.859 & 18.8 & 0.626 & 0.237 & 1.05 & 0.97 \\
\hline 368 & 0.588 & 22.7 & 0.628 & 0.254 & 1.13 & 0.97 \\
\hline
\end{tabular}

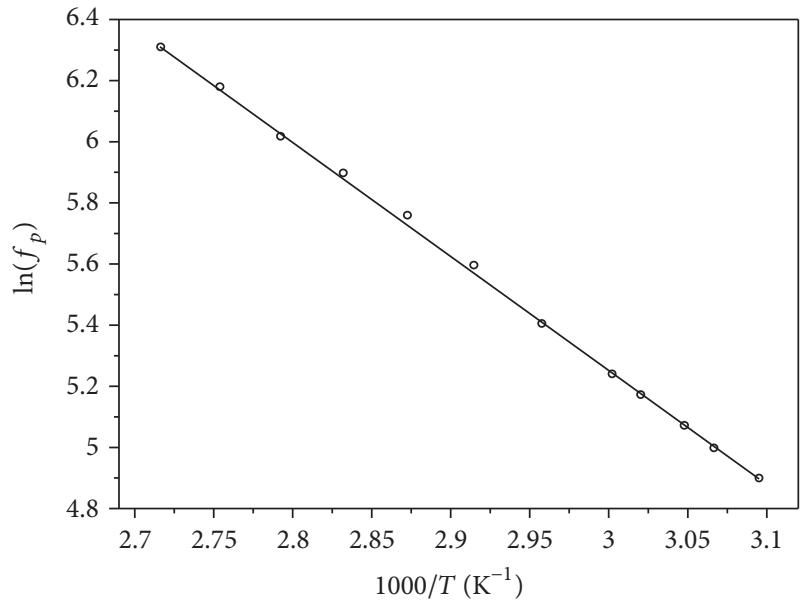

FIGURE 12: Dependence of $\operatorname{Ln}\left(f_{p}\right)$ versus reciprocal temperature for $\left[\left(\mathrm{C}_{3} \mathrm{H}_{7}\right)_{4} \mathrm{~N}\right]_{2} \mathrm{Hg}_{2} \mathrm{Cl}_{6}$ sample.

the temperature for which the measuring frequency is equal to $f_{p}$ is also high.

The conductivity relaxation frequency $f_{p}$ is given by the relation $f_{p}=f_{0} \exp \left(E_{m} /\left(K_{\beta} T\right)\right)$, where $f_{0}$ is the characteristic phonon frequency, $E_{m}$ is the activation energy for conductivity relaxation, $K_{\beta}$ is the Boltzmann's constant, and $T$ is the temperature. The temperature dependence of the conductivity relaxation frequency is plotted in Figure 12. It is well described by the Arrhenius relation. The activation energy $E_{m}$ obtained from the modulus spectra is about $0.4 \mathrm{eV}$.

The activation energies issued from the impedance $E_{b}$ $(0.46 \mathrm{eV})$ and modulus $E_{m}(0.4 \mathrm{eV})$ spectra are not very different, to suggest that the ion transport in polycrystalline sample is probably due to a hopping mechanism [37].

\section{Conclusion}

Crystals of a new hybrid material, $\left[\left(\mathrm{C}_{3} \mathrm{H}_{7}\right)_{4} \mathrm{~N}\right]_{2} \mathrm{Hg}_{2} \mathrm{Cl}_{6}$, have been prepared by slow evaporation of aqueous solution $\mathrm{HCl}(1 \mathrm{M}), \mathrm{N}\left(\mathrm{C}_{3} \mathrm{H}_{7}\right)_{4}$, and $\mathrm{HgCl}_{2}$ at room temperature.
The atomic arrangement is layered organization of organicinorganic sheets staked along $b$ direction. Those layers spreading in this network are interconnected by van Der Waals interaction. The analysis of the frequency dispersion of the real imaginary components of the complex impedance allowed us to determine an equivalent electrical circuit for the electrochemical cell with $\left[\left(\mathrm{C}_{3} \mathrm{H}_{7}\right)_{4} \mathrm{~N}_{2} \mathrm{Hg}_{2} \mathrm{Cl}_{6}\right.$. The temperature dependence of conductivity was analyzed using the Arrhenius approach. Impedance spectra revealed the presence of grain and grain boundary contribution whereas electric modulus spectra showed only bulk (grain) contribution in the electrical properties.

The analysis of the temperature variation of $M^{\prime \prime}$ peak indicates that the observed relaxation process is thermally activated. The near value of activation energies is obtained from the relaxation times $(0.4 \mathrm{eV})$ and conductivity data $(0.46 \mathrm{eV})$ suggesting that the ionic transport in the investigated material can be described by a hopping mechanism.

\section{References}

[1] H. Suzuki, K. Notsu, Y. Takeda, W. Sugimoto, and Y. Sugahara, "Reactions of alkoxyl derivatives of a layered perovskite with alcohols: substitution reactions on the interlayer surface of a layered perovskite," Chemistry of Materials, vol. 15, no. 3, pp. 636-641, 2003.

[2] M. Ogawa and K. Kuroda, "Preparation of inorganic-organic nanocomposites through intercalation of organoammonium ions into layered silicates," Bulletin of the Chemical Society of Japan, vol. 70, no. 11, pp. 2593-2618, 1997.

[3] A. M. Guloy, Z. Tang, P. B. Miranda, and V. I. Srdanov, "A new luminescent organic-inorganic hybrid compound with large optical nonlinearity," Advanced Materials, vol. 13, no. 11, pp. 833-837, 2001.

[4] K. Chondroudis and D. B. Mitzi, "Electroluminescence from an organic-inorganic perovskite incorporating a quaterthiophene dye within lead halide perovskite layers," Chemistry of Materials, vol. 11, no. 11, pp. 3028-3030, 1999.

[5] M. A. Pitt and D. W. Johnson, "Main group supramolecular chemistry," Chemical Society Reviews, vol. 36, no. 9, pp. 1441-1453, 2007. 
[6] G. Mahmoudi and A. Morsali, "Counter-ion influence on the coordination mode of the 2,5-bis(4-pyridyl)-1, 3,4-oxadiazole (bpo) ligand in mercury(ii) coordination polymers, $\left[\mathrm{Hg}(\mathrm{bpo})_{n} \mathrm{X}_{2}\right]: \mathrm{X}=\mathrm{I}^{-}, \mathrm{Br}^{-}, \mathrm{SCN}^{-}, \mathrm{N}_{3}{ }^{-}$and $\mathrm{NO}_{2}{ }^{-}$; spectroscopic, thermal, fluorescence and structural studies," CrystEngComm, vol. 9, no. 11, pp. 1062-1072, 2007.

[7] P. Kubinec, E. Birks, W. Schranz, and A. Fuith, "Ultrasonic study of normal-incommensurate-commensurate phase transitions in $\left[\mathrm{N}\left(\mathrm{CH}_{3}\right)_{4}\right]_{2} \mathrm{MnCl}_{4}$, Physical Review B, vol. 49 , no. 10 , pp. 6515-6521, 1994.

[8] Y. Kato, D. Ichii, K. Ohashi et al., "Extremely large binding energy of biexcitons in an organic-inorganic quantum-well material $\left(\mathrm{C}_{4} \mathrm{H}_{9} \mathrm{NH}_{3}\right)_{2} \mathrm{PbBr}_{4}$," Solid State Communications, vol. 128, no. 1, pp. 15-18, 2003.

[9] A. El-Korashy and M. G. Brik, "Crystal growth, spectroscopic and crystal field studies of $\left[\mathrm{N}\left(\mathrm{CH}_{3}\right)_{4}\right]_{2} \mathrm{MnCl}_{4}$ and $\left[\mathrm{N}\left(\mathrm{CH}_{3}\right)_{4}\right]_{2} \mathrm{CoCl}_{4}$ single crystals in the paraelectric phase," Solid State Communications, vol. 135, no. 5, pp. 298-303, 2005.

[10] G. Lach, L. Laskowski, I. V. Kityk et al., "Dielectric relaxation of $\left(\mathrm{N}\left(\mathrm{C}_{2} \mathrm{H}_{5}\right)_{4}\right)_{2} \mathrm{CoCl}_{2} \mathrm{Br}_{2}$ nanocrystallites incorporated into the PMMA matrix," Journal of Non-Crystalline Solids, vol. 353, no. 47-51, pp. 4353-4356, 2007.

[11] A. Morsali and M. Y. Masoomi, "Structures and properties of mercury(II) coordination polymers," Coordination Chemistry Reviews, vol. 253, no. 13-14, pp. 1882-1905, 2009.

[12] A. Oueslati, F. Hlel, K. Guidara, and M. Gargouri, "AC conductivity analysis and dielectric relaxation behavior of $\left[\mathrm{N}\left(\mathrm{C}_{3} \mathrm{H}_{7}\right)_{4}\right]_{2} \mathrm{Cu}_{2} \mathrm{Cl}_{6}$," Journal of Alloys and Compounds, vol. 492, no. 1-2, pp. 508-514, 2010.

[13] N. Hannachi, A. Bulou, and F. Hlel, "Structural characterization and $\mathrm{AC}$ conductivity of bis tetrapropylammonium hexachlorado-dicadmate, $\left[\mathrm{N}\left(\mathrm{C}_{3} \mathrm{H}_{7}\right)_{4}\right]_{2} \mathrm{Cd}_{2} \mathrm{Cl}_{6}$," Materials Research Bulletin, vol. 45, no. 11, pp. 1754-1761, 2010.

[14] G. M. Sheldrick, SADABS, University of Göttingen, Göttingen, Germany, 2004.

[15] G. M. Sheldrick, Program for Crystal Structure Solution, SHELXS-97, University of Göttingen, Göttingen, Germany, 1986.

[16] G. M. Sheldrick, Program for Crystal Structure Refinement, SHELXS-97, University of Göttingen, Göttingen, Germany, 1986.

[17] G. Hu and E. M. Holt, "Bis(tetrapropylammonium) hexachlorodicuprate(II)," Acta Crystallographica, vol. 50, pp. 1212-1214, 1994.

[18] S. L. Moustarder, N. Mercier, P. Hudhomme, N. GallegoPlanas, A. Gorgues, and A. Riou, "Copper(I) coordination ability of the outer S-position isomer of EDT-DMT-TTF (Dl): crystal structure of $(\mathrm{Dl})_{2} \mathrm{Cu}_{2} \mathrm{Br}_{4,2} \mathrm{CH}_{2} \mathrm{Cl}_{2}$ : structural correlation with the (Dl) ${ }_{2} \mathrm{Cu}_{2} \mathrm{Br}_{6}$ copper(II) salt," Synthetic Metals, vol. 130, no. 2, pp. 129-134, 2002.

[19] W. Brown, Acta Crystallographica B, vol. 30, p. 1195, 1974.

[20] A. Oueslati, F. Hlel, and M. Gargouri, "Preparation and characterization of organic-inorganic hybrid compound $\left[\mathrm{N}\left(\mathrm{C}_{4} \mathrm{H}_{9}\right)_{4}\right]_{2} \mathrm{Cu}_{2} \mathrm{Cl}_{6}$, Ionics, vol. 17, no. 1, pp. 91-98, 2011.

[21] J. Tarasiewicz, R. Jakubas, J. Baran, and A. Pietraszko, "Thermal, dielectric properties and vibrational spectra of [n$\left.\mathrm{C}_{4} \mathrm{H}_{9} \mathrm{NH}_{3}\right]_{2}\left[\mathrm{BiBr}_{5}\right]$ crystal," Journal of Molecular Structure, vol. 792-793, pp. 265-273, 2006.

[22] A. Ouasri, A. Rhandour, M. C. Dhamelincourt, P. Dhamelincourt, and A. Mazzah, "Vibrational study of $\left(\mathrm{CH}_{3}\right)_{4} \mathrm{NSbCl}_{6}$ and
$\left[\left(\mathrm{CH}_{3}\right)_{4} \mathrm{~N}\right]_{2} \mathrm{SiF}_{6}$," Spectrochimica Acta Part A, vol. 58, no. 12, pp. 2779-2788, 2002.

[23] M. Góśniowska, Z. Ciunik, G. Bator, R. Jakubas, and J. Baran, "Structure and phase transitions in tetramethylammonium tetrabromoindate(III) and tetraethylammonium tetrabromoindate(III) crystals," Journal of Molecular Structure, vol. 555, pp. 243-255, 2000.

[24] J. Tarasiewicz, R. Jakubas, J. Baran, and A. Pietraszko, "On the structural phase transitions in $\left[\mathrm{n}-\mathrm{C}_{4} \mathrm{H}_{9} \mathrm{NH}_{3}\right]_{2}\left[\mathrm{SbBr}_{5}\right]$ : thermal, dielectric and infrared studies," Journal of Molecular Structure, vol. 697, no. 1-3, pp. 161-171, 2004.

[25] N. Hannachi, K. Guidara, A. Bulou, M. Gargouri, and F. Hlel, "Polarized Raman study of $\left[\mathrm{N}\left(\mathrm{C}_{3} \mathrm{H}_{7}\right)_{4}\right]_{2} \mathrm{Cd}_{2} \mathrm{Cl}_{6}$ single crystal," Spectrochimica Acta Part A, vol. 77, no. 2, pp. 457-460, 2010.

[26] F. Hlel, A. Rheim, T. Guerfel, and K. Guidara, "Synthesis, calorimetric study, infrared spectroscopy and crystal structure investigation of $\beta$-[tetraethylammonium tetramethylammonium tetrachlorozincate(II)] [ $\beta]-\left[\left(\mathrm{C}_{2} \mathrm{H}_{5}\right)_{4} \mathrm{~N}\right]\left[\left(\mathrm{CH}_{3}\right)_{4} \mathrm{~N}\right] \mathrm{ZnCl}_{4}$, Zeitschrift fur Naturforschung Section B, vol. 61, no. 8, pp. 1002-1006, 2006.

[27] A. Ben Rhaiem, F. Hlel, K. Guidara, and M. Gargouri, "Vibrational study of $\left[\left(\mathrm{CH}_{3}\right)_{4} \mathrm{~N}\right]_{2} \mathrm{Cu}_{0.5} \mathrm{Zn}_{0.5} \mathrm{Cl}_{4}$," Spectrochimica Acta Part A, vol. 66, no. 4-5, pp. 1107-1109, 2007.

[28] A. Ben Rhaiem, K. Guidara, M. Gargouri, and A. Daoud, "Electrical properties and equivalent circuit of trimethylammonium monobromodichloromercurate," Journal of Alloys and Compounds, vol. 392, no. 1-2, pp. 68-71, 2005.

[29] D. K. Parathan, B. K. Samantry, R. N. P. Chauthaey, and A. K. Thakur, Materials Science and Engineering B, vol. 116, p. 431, 2005.

[30] M. Nadeem, M. J. Akhtar, and A. Y. Khan, "Effects of low frequency near metal-insulator transition temperatures on polycrystalline $\mathrm{La}_{0.65} \mathrm{Ca}_{0.35} \mathrm{Mn}_{1-y} \mathrm{Fe}_{y} \mathrm{O}_{3}$ (where $y=0.05-0.10$ ) ceramic oxides," Solid State Communications, vol. 134, no. 6, pp. 431-436, 2005.

[31] J. T. S. Irvine, D. C. Sinclair, and A. R. West, "Electroceramics: characterization by impedance spectroscopy," Advanced Materials, vol. 2, no. 3, pp. 132-138, 1990.

[32] J. Liu, C. G. Duan, W. G. Yin, W. N. Mei, R. W. Smith, and J. R. Hardy, "Dielectric permittivity and electric modulus in $\mathrm{Bi}_{2} \mathrm{Ti}_{4} \mathrm{O}_{11}$," Journal of Chemical Physics, vol. 119, no. 5, pp. 2812-2819, 2003.

[33] P. B. Macedo, C. T. Moynihan, and R. Bose, Physics and Chemistry of Glasses, vol. 13, article 0171, 1972.

[34] R. Gerhardt, "Impedance and dielectric spectroscopy revisited: distinguishing localized relaxation from long-range conductivity," Journal of Physics and Chemistry of Solids, vol. 55, no. 12, pp. 1491-1506, 1994.

[35] A. R. James, S. Priya, K. Uchino, and K. Srinivas, "Dielectric spectroscopy of $\mathrm{Pb}\left(\mathrm{Mg}_{1 / 3} \mathrm{Nb}_{2 / 3}\right) \mathrm{O}_{3}-\mathrm{PbTiO}_{3}$ single crystals," Journal of Applied Physics, vol. 90, no. 7, pp. 3504-3508, 2001.

[36] F. Borsa, D. R. Torgeson, S. W. Martin, and H. K. Patel, "Relaxation and fluctuations in glassy fast-ion conductors: wide-frequency-range NMR and conductivity measurements," Physical Review B, vol. 46, no. 2, pp. 795-800, 1992.

[37] K. Karoui, A. Ben Rhaiem, and K. Guidara, "Electrical characterization of the $\left[\mathrm{N}\left(\mathrm{CH}_{3}\right)_{4}\right]\left[\mathrm{N}_{2}\left(\mathrm{C}_{2} \mathrm{H}_{5}\right)_{4}\right] \mathrm{ZnCl}_{4}$ compound," Ionics, vol. 17, no. 6, pp. 517-525, 2011. 

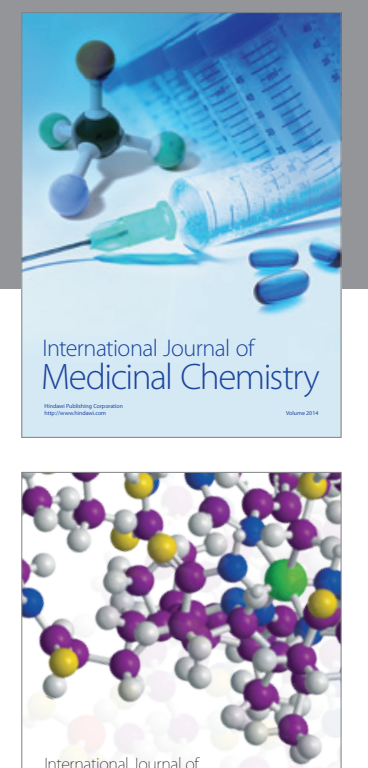

\section{Carbohydrate} Chemistry

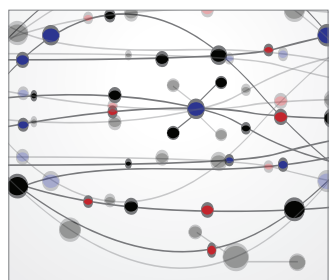

The Scientific World Journal
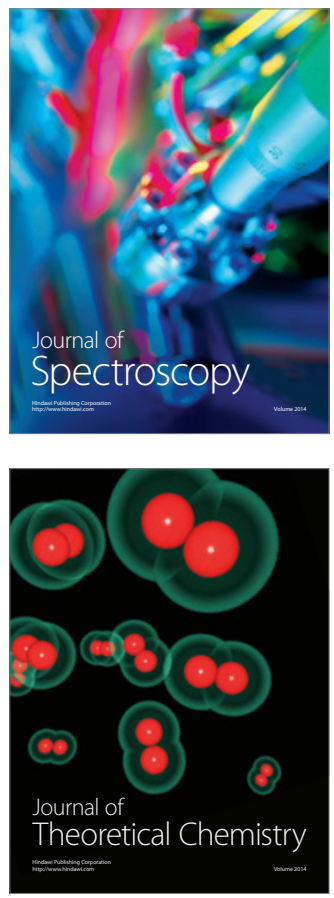
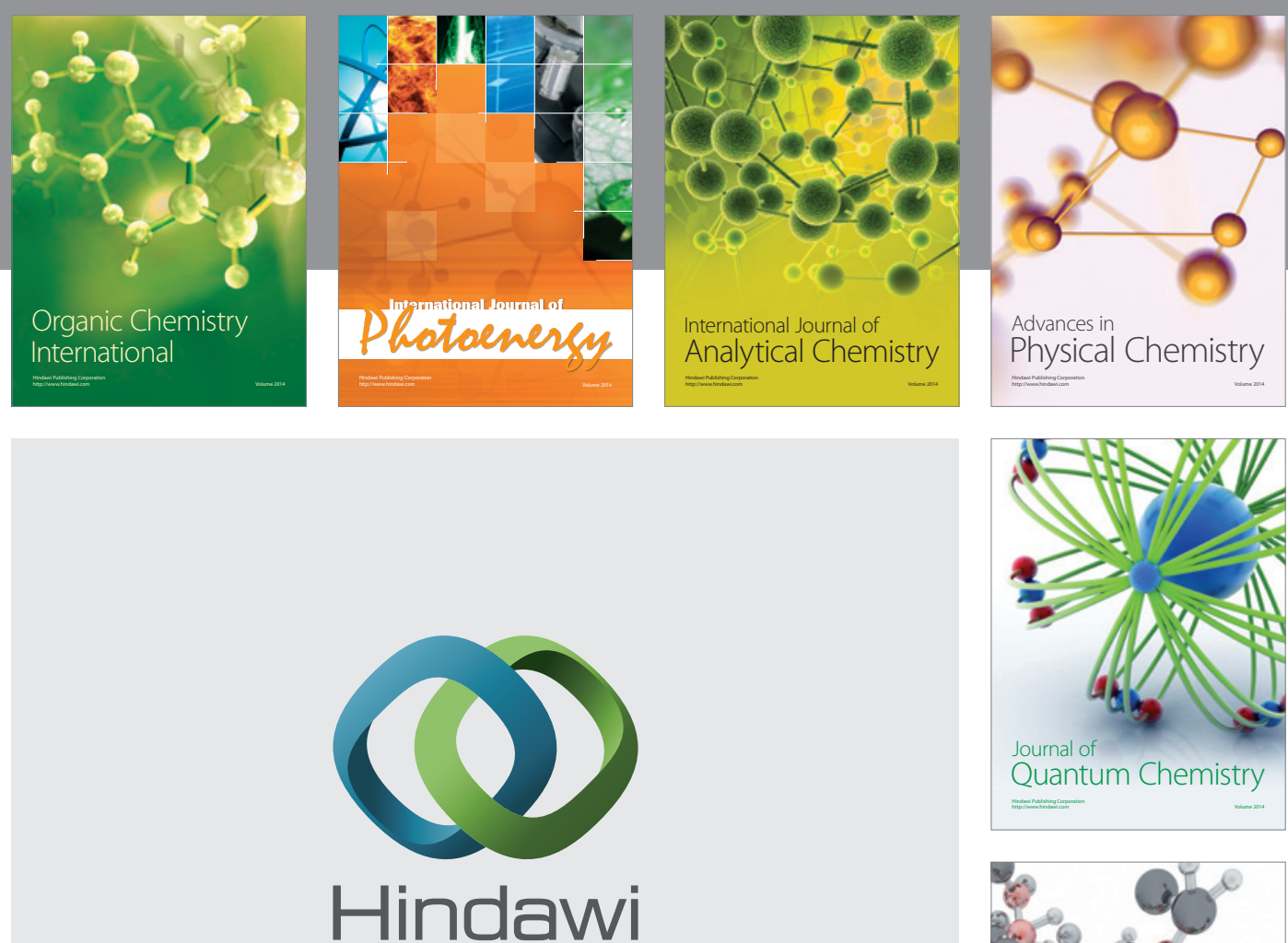

Submit your manuscripts at

http://www.hindawi.com

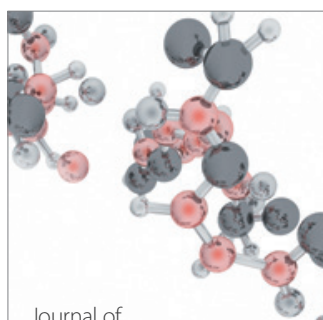

Analytical Methods

in Chemistry

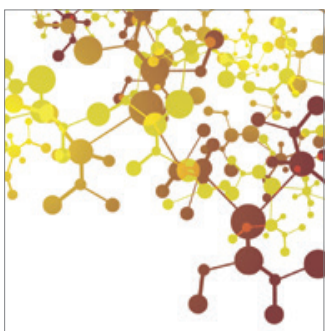

Journal of

Applied Chemistry

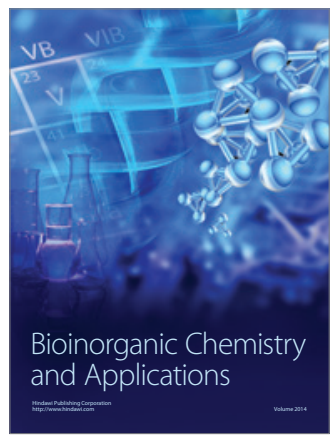

Inorganic Chemistry
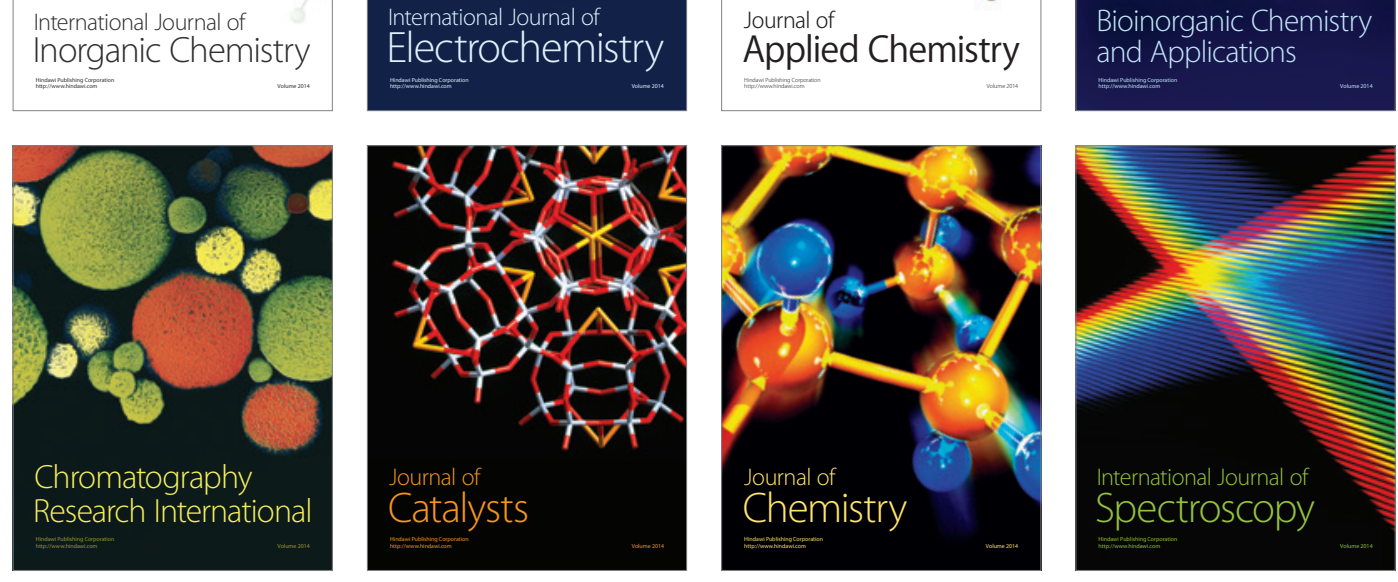